\title{
VARIABILITY OF YIELD AND YIELD COMPONENTS IN “EGUSI” MELON
}

\author{
P.E. OGBONNA and I.U. OBI \\ Department of Crop Science, University of Nigeria, Nsukka, 410001, Nigeria \\ Corresponding author: ogbonnaptr@yahoo.com
}

(Received 30 November, 2009; accepted 5 September, 2010)

\begin{abstract}
Egusi melon (Citrullus lanatus (Thunb.) Mansf.) is an important food crop in Nigeria and other African countries. In a study carried out to estimate the components of variation in 'egusi' melon populations indicated high proportion of genetic variation in the yield attributes measured. Estimates of phenotypic coefficient of variation ranged between 3.6-52\%, while genotypic coefficient of variation ranged between $3.21-51 \%$ for seed yield plant $^{-1}$, number of fruits plant ${ }^{-1}$ and fruit yield plant ${ }^{-1}$. Heritability estimate was high in the yield attributes. On seed yield plant ${ }^{-1}$, heritability ranged between $83-98 \%$. Estimate of expected genetic advance in seed yield plant ${ }^{-1}$ ranged between 25.90-48.40\%. Improvement could be made in seed yield through selection.
\end{abstract}

Key Words: Breeding populations, heritability, Nigeria, selection

\section{RÉSUMÉ}

Le melon "Egusi" (Citrullus lanatus (Thunb.) Mansf.) est une important culture alimentaire au Nigeria et autres pays africains. Une étude portée sur l'estimation des composants de variation des populations du melon "Egusi" avait indiqué une proportion élevée de la variation génétique dans les caractéristiques mesurées. Pour le rendement en grain et le nombre de fruits par plant, le coefficient de variation phénotypique et génotypique variait de 3.6-52\% et de 3.21-51\% respectivement. L'estimation de l'héritabilité était élevée dans les paramètres de rendement avec des valeurs d'héritabilité variant entre 83 et $98 \%$ pour le rendement en grain par plant. L'estimation de l'amélioration génétique expectée du rendement en grain par plant variait entre 25.90-48.40\%. L'amélioration du rendement en grain pourrait être faite sur base de sélection.

Mots Clés: Hybridation de populations, héritabilité, Nigeria, sélection

\section{INTRODUCTION}

Egusi melon (Citrullus lanatus (Thunb.) Mansf.) is an important food crop in Nigeria and other African countries. It is grown for the seed which is rich in protein $(33.8 \%)$ (Oyolu and Macfarlene, 1982) and is use in preparing assorted dishes, especially soup. The seeds also contain high quantity of edible oil $(56.1 \%)$ (Oyolu and Macfarlene, 1982), and could be classified as a minor oil seed crop. There is, however, a dearth of information on the genetics and breeding of this important crop.
Gabriele and Todd (2004) had noted that part of the improvement made in yield of watermelon may be attributed to its genetic improvement. It is, therefore, important in choosing an appropriate breeding programme for improving yield in any crop to know the mean value, variability, heritability of the and yield components. In wheat, phenotypic and genotypic variances, heritability and genetic advance have been used to estimate the degree of variances in yield (Bhutta, 2006; Tazeen et al., 2009). It has been pointed out that in population improvement, it is imperative to determine the 
extent of genetic variation for a trait to be improved (Flores et al., 1986).

The basic idea in the study of variation is its partitioning into components attributable to different causes and the relative magnitude of these components determines the genetic properties of the population (Falconer, 1989). This led to the concept of heritability, which specifies the proportion of the total variation that is due to genetic causes. Determining the components of variability in yield and its components will also enable us to know the extent of environmental influence on yield, taking into consideration of the fact that yield and its components are quantitative characters and are affected by environment (Ahmed et al., 2007).

Heritability provides an idea to the extent of genetic control for expression of a particular trait and the reliability of phenotype in predicting its breeding value (Chopra, 2000; Tazeen et al., 2009).High heritability indicates less environmental influence in the observed variation (Mohanty, 2003; Ansari et al., 2004; Songsri et al., 2008; Eid, 2009). It also gives an estimate of genetic advance a breeder can expect from selection applied to a population and help in deciding on what breeding method to chose (Hamdi et al., 2003; Gatti et al., 2005).

Genetic advance which estimates the degree of gain in a trait obtained under a given selection pressure is another important parameter that guides the breeder in choosing a selection programme (Hamdi et al., 2003; Shukla et al., 2004). High heritability and high genetic advance for a given trait indicates that it is governed by additive gene action and, therefore, provides the most effective condition for selection (Tazeen et al., 2009).

The objective of this research was to estimate the magnitude of the various components of variation, heritability and genetic advance in Egusi melon populations with a view to recommending breeding methods for the improvement of the crop.

\section{MATERIALS AND METHODS}

The research was conducted at the Department of Crop Science Experimental Farm, University of Nigeria Nsukka located on lat. $06^{\circ} 52^{\prime} \mathrm{N}$ and long. $07^{\circ} 24^{\prime} \mathrm{E}$ and altitude of 447 metres. The study was done in the planting seasons (March to August) of 2005, 2006 and 2007. The materials used in the study were eight inbred lines of "egusi" melon; NS.B, NS.W, NS.R, NS.E, OV.I, "serewe", W.SE and B.SE. These were collected from the Department of Crop Science, University of Nigeria, Nsukka, seed collection.

Crosses were made among the inbred lines and the following $F_{1 s}$ were obtained; NS.B $\times$ NS.W, NS.E $\times$ NS.R, "serewe" W.SE, OV.1 W.SE and OV.1 B.SE. These $F_{1 s}$ were selfed and crossed to their respective parents to obtain their $\mathrm{F}_{2 \mathrm{~s}}$ and backcrosses. The inbred parents, $\mathrm{F}_{1}, \mathrm{~F}_{2}, \mathrm{BCP}_{1}$ and $\mathrm{BCP}_{2}$ of each cross were evaluated in a randomised complete block design (RCBD) with three replications.

At maturity the fruits were gathered accordingly and later processed to extract the seeds. The following yield attributes were measured; number of fruits plant ${ }^{-1}$, fruit yield plant $^{-1}$, average fruit weight, seed yield plant ${ }^{-1}$, number of seeds fruit ${ }^{-1}$ and 100 seed weight.

Analysis of variance and estimate of phenotypic, genotypic and error variances were done according to the method described by Uguru (1998). Broad sense heritability (Hbs) was estimated according to the procedure described by Poehlman (1987) as follows:

Hbs $=\frac{\sigma^{2} g}{\sigma^{2} p h} \times \frac{100}{1}$

Phenotypic and genotypic coefficients of variation (PCV and GCV) were estimated using the method outlined by Burton and Devane (1953) as follows:

$$
\begin{aligned}
& \mathrm{PCV}=\sqrt{\frac{\sigma^{2} p h}{\bar{X}}} \times \frac{100}{1} \% \\
& \mathrm{GCV}=\sqrt{\frac{\sigma^{2} g}{\bar{X}}} \times \frac{100}{1} \%
\end{aligned}
$$

Expected genetic advance (Gs) under selection for each trait was calculated according to Allard (1980) as follows: 
Gs $=(\mathrm{K})(\sigma \mathrm{ph})(\mathrm{H})$ where

Gs = expected genetic advance under selection $\mathrm{K}=$ selection differential which varied with selection intensity (5\% intensity was used at which $\mathrm{K}=2.06$ )

$\begin{aligned} \sigma \mathrm{ph} & =\text { phenotypic standard deviation } \\ \mathrm{H} & =\text { heritability }\end{aligned}$

\section{RESULT}

The results presented in Table 1 indicate that the total variation observed in the populations was mainly of genetic origin. This accounted for over $50 \%$ in most of the attributes measured in all crosses. Both PCV and GCV were low in all crosses (Table 2). It was also noted that PCV was always higher than the GVC for all attributes in the crosses. Seed yield plant ${ }^{-1}$ recorded the highest coefficient of variation among the attributes in the crosses; while 100 seed weight had the lowest. Heritability estimate indicated high broad sense heritability in almost all attributes measured (Table 3). Low heritability was only recorded on number of seeds fruit ${ }^{-1}$ on crosses OV.1W.SE and OV.1B.SE. Also, in cross OV.1W.SE, seed yield fruit ${ }^{-1}$ had low heritability estimate.

The expected genetic advance in selection (Gs) was high relative to the population mean in all the attributes (Table 4). Seed yield plant ${ }^{-1}$ and number of seeds plant ${ }^{-1}$ in NS.BNS.W had Gs that were higher than the population mean. In other crosses, Gs was always greater than half the population mean in seed yield plant ${ }^{-1}$. Lowest Gs among all attributes was recorded in 100seed weight in all crosses.

\section{DISCUSSION}

High proportion of genetic variation (Table 1) implies that genetic variation plays an important role in the inheritance of yield attributes in "egusi" melon. Raje and Rao (2000) noted that genetic variability is essential in order to realise response to selection pressure. The high proportion of genetic variation recorded in the yield attributes is an indication of high response to selection. It has also been pointed out that

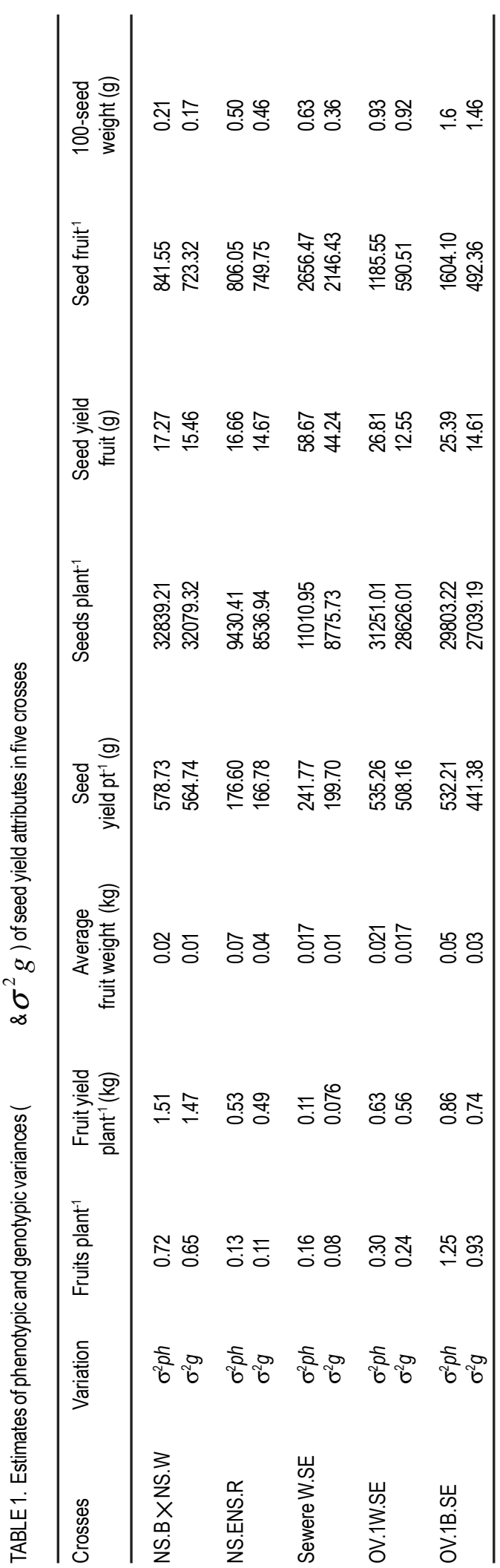


the magnitude of genetic variability present in base population of any crop species is important in crop improvement and must be exploited by plant breeders for yield improvement (Idahosa et al., 2010).

The high PCV and GCV recorded in seed yield attributes (Table 2) agrees with the findings of Kehinde and Idehen (2008) on the crop. High GCV in some fruit and seed yield attributes in round melon has also been reported (Samadia, 2007). There are indications that these attributes had to some extent interacted with the environment. This was manifested by the higher magnitude of phenotypic coefficient of variation relative to the corresponding genotypic coefficient of variation in all the attributes. However, since the PCV and GCV values were close to one another, implies that genotype contributed more to the expression of these characters than environment, suggesting greater possibilities of improvement through selection (Rakhi and Rajamony, 2005). Since coefficient of variation compares the relative amount of variability among attributes, it could, therefore, be deduced that seed yield plant ${ }^{-1}$ and number of seeds plant ${ }^{-1}$ had higher amount of exploitable genetic variability among the attributes. It also signifies that there is greater potential for favourable advance in selection in these attributes compared with others (Eid, 2009).

High heritability recorded in the yield attributes in this study (Table 3) implies large genetic effect and might have resulted from the fact that there are great differences among the parents used in the research. Such high heritability values in fruit and seed yield characters have been reported in culinary melon, cucumber and muskmelon (Rakhi and Rajamony, 2005; Mariappan and Pappiah, 2007; Taha et al., 2007). The high heritability, therefore, implies that these yield attributes are controlled genetically, signifying high potential for improvement through selection. It will be noted that high heritability alone may not necessary result in increased genetic gain, without sufficient genetic variability in the germplasm (Sardana et al., 2007). However, the high heritability and high expected genetic advance recorded in most of the yield attributes further confirms that these attributes are governed by 
Variability of yield and yield components

TABLE 3. Estimates of heritability in the broad sense ( $\mathrm{Hbs}$ ) of yield attributes in the five crosses

\begin{tabular}{|c|c|c|c|c|c|c|c|c|c|}
\hline Crosses & Heritability & Fruits plant ${ }^{-1}$ & $\begin{array}{l}\text { Fruit yield } \\
\text { plant }^{-1}(\mathrm{~kg})\end{array}$ & $\begin{array}{c}\text { Average } \\
\text { fruit } \\
\text { weight }(\mathrm{kg})\end{array}$ & $\begin{array}{c}\text { Seed } \\
\text { yield } \\
\text { plant }^{-1}(\mathrm{~g})\end{array}$ & $\begin{array}{l}\text { Seeds } \\
\text { plant }^{-1}\end{array}$ & $\begin{array}{l}\text { Seed } \\
\text { yield } \\
\text { fruit }^{-1}(\mathrm{~g})\end{array}$ & $\begin{array}{r}\text { Seeds } \\
\text { fruit }^{-1}\end{array}$ & $\begin{array}{l}100 \text {-seed } \\
\text { weight }(\mathrm{g})\end{array}$ \\
\hline$N S-B \times N S-W$ & $\mathrm{H}_{\mathrm{bs}}$ & 90.28 & 97.42 & 70.59 & 97.58 & 97.69 & 89.52 & 85.95 & 80.74 \\
\hline NS-E x NS-R & $\mathrm{H}_{\mathrm{bs}}$ & 84.62 & 92.45 & 93.12 & 94.44 & 90.53 & 88.06 & 93.02 & 92.00 \\
\hline Sewere $\times$ W.SE & $\mathrm{H}_{\mathrm{bs}}^{\mathrm{bs}}$ & 50.00 & 72.80 & 59.64 & 82.60 & 79.70 & 75.40 & 80.80 & 57.10 \\
\hline OV.1xW.SE & $\mathrm{H}_{\mathrm{bs}}^{\mathrm{os}}$ & 80.00 & 88.90 & 80.95 & 94.94 & 91.60 & 46.81 & 49.70 & 98.90 \\
\hline OV.1 xB.SE & $H_{b s}^{b s}$ & 74.40 & 86.10 & 54.20 & 82.90 & 90.70 & 57.54 & 30.69 & 91.31 \\
\hline
\end{tabular}

additive gene action implying that significant improvement could be made in yield through selection in 'egusi' melon (Eid, 2009).

\section{REFERENCES}

Ahmed, N.C.B. and Khaliq, I.M.M. 2007. The inheritance of yield and yield components of five wheat hybrid populations under drought conditions. Indonesian Journal of Agricultural Science 8(2):53-59.

Allard, R.W. 1980. Principles of Plant Breeding. John Wiley and Sons Inc. New York. 485pp.

Ansari, B.A., Ansari, K.A. and Khund, A. 2004. Extent of heterosis and heritability in some quantitative characters of bread wheat. Industrial Journal of Plant Science 3:189192.

Bhutta, W. M. 2006. Role of some agronomic traits for grain yield production in wheat (Triticum aestivum L.) genotypes under drought conditions. Revista UDO Agricola 6:11-19.

Burton, G.W. and DeVane, E.H. 1953. Estimating heritability in tall fescus from replicated clonal material. Agricultural Journal 45:478-481.

Chopra, V.L 2000. Plant Breeding. Theory and Practice. $2^{\text {nd }}$ ed. Oxford and IBH Pub. Co. Pvt. New Delhi. pp. 10.

Eid, M.H. 2009. Estimation of heritability and genetic advance of yield traits in wheat (Triticum aestivum L.) under drought conditions. International Journal of Genetics and Molecular Biology 1(7):115120.
Falconer, D.S. 1989. Introduction to Quantitative Genetics. John Wiley and Sons Inc. New York $439 \mathrm{pp}$.

Flores, C.I., Ross, W.M. and Maranville, J.W. 1986. Quantitative genetics of agronomic and nutritional traits in related grain sorghum random-mating population as affected by selection Crop Science 26(1):9-18.

Gabriele, G. and Todd, C.W. 2004. Estimates of variance components and broad sense heritability for yield in watermelon. Cucurbit Genetics Cooperative Report 27:45-48.

Gatti, I., Anido, F.L., Vanina, C, Asprelli, P.and Country, E. 2005. Heritability and expected selection response for yield traits in blanched asparagus. Genetics and Molecular Research 4(1):67-73.

Hamdi, A., El-Chareib, A.A., Shafey, S.A. and Ibrahim, M.A.M 2003. Genetic variability, heritability and expected genetic advance for earliness and seed yield from selections in lentil. Egypt Journal of Agricultural Research 81(1):125-137.

Idahosa, D.O., Alika, J.E. and Omoregie, A.U. 2010. Genetic variability, heritability and expected genetic advance as indices for yield and yield components selection in cowpea (Vigna unguiculata (L) Walp). Academia Arena 2 (5):22-26.

Kehinde,O.B. and Idehen, E.O. 2008. Genetic variability and correlation studies in "egusi" melon [Citrullus lanatus (Thunb) Matsum \& Nakai]. Acta Agronomica Hungarica 56(2):213-221. 
Mariappan, S. and Pappiah, C.M. 2007. Genetic studies in cucumber ( $C$ sativus L.). South Indian Horticulture 38:70-74.

Mohanty, B.K. 2003. Genetic variability, heritability, correlation and path coefficient studies in tomato. Indian Journal of Agricultural Research 37:68-71.

Oyolu, C. and Macfarlene, N. 1982. A study of the oil and soluble protein components of five Egusi (Colocynthis citrullus L.) cultivars. Tropical Science 24(2):93-98.

Poehlman, J.M. 1987. Breeding Field Crops. $3^{\text {rd }}$ Edition. Van Nostrand Reinhold. New York. 724 pp.

Raje, R.S. and Rao, S.K. 2000. Genetic parameters of variation for and its components in mungbean (Vigna unguiculata $(\mathrm{L})$ Wilc.) over environments. Legume Research 23(4):211-216.

Rakhi, R. and Rajamony, L. 2005. Variability, heritability and genetic advance in landraces of culinary melon (Cucumis melo L.). Journal of Tropical Agriculture 43(12):79-82.

Sardana, S., Mahjan, R., Gautam, N. and Ram, B. 2007. Genetic variability in pea (Pisum sativum) germplasm for utilisation. SABRAO Journal of Breeding and Genetics 39(10):31-41.

Samadia, D.K. 2007. Studies on genetic variability and scope of improvement in round melon under hot arid condition. Indian Journal of Horticulture 64(1).

Shukla, S., Bhargava, A., Chattergee, A. and Singh, S.P. 2004. Estimates of genetic parameters to determine variability for foliage yield and its different quantitative and qualitative traits in vegetable amaranth $(A$. tricolor). Journal of Genetics and Breeding 58:169-176.

Songsri, P., Joglloy, S., Kesmala, T., Vorasoot, N., Akkasaeng, C.P.A. and Holbrook, C. 2008. Heritability of drought resistant traits and correlation of drought resistance and agronomic traits in peanut. Crop Science 48:2245-2253.

Taha, M., ElJack, A.E. and Omara, S. 2007. Estimation of genetic variability and broad sense heritability of some traits in melon 
(Cucumis melo. L.). Sudan Journal of Agricultural Research 8:51-57.

Tazeen, M., Nadia, K. and Farzana, N.N. 2009.

Heritability, phenotypic correlation and path

coefficient studies for some agronomic characters in synthetic elite lines of wheat. Journal of Food, Agriculture and Environment 7(3 and 4):278-282.

Uguru, M.I. 1998. Crop Genetics and Breeding. The Comic Printer Nigeria. 115 pp. 